\title{
Capital Structure, Working Capital, and Governance Quality Affect the Financial Performance of Small and Medium Enterprises in Taiwan
}

\author{
Anh-Huyen Vu Thi ${ }^{1}$ and The-Dong Phung ${ }^{2, *}$ \\ 1 Academy of Policy and Development, Hanoi 100000, Vietnam; vuanhhuyen96@gmail.com \\ 2 National Financial Supervisory Commission, Hanoi 100000, Vietnam \\ * Correspondence: dongpt@nfsc.gov.vn
}

\section{check for} updates

Citation: Vu Thi, Anh-Huyen, and The-Dong Phung. 2021. Capital Structure, Working Capital, and Governance Quality Affect the Financial Performance of Small and Medium Enterprises in Taiwan. Journal of Risk and Financial Management 14: 381. https:// doi.org/10.3390/jrfm14080381

Academic Editor: Aviral

Kumar Tiwari

Received: 8 July 2021

Accepted: 13 August 2021

Published: 17 August 2021

Publisher's Note: MDPI stays neutral with regard to jurisdictional claims in published maps and institutional affiliations.

Copyright: (c) 2021 by the authors. Licensee MDPI, Basel, Switzerland. This article is an open access article distributed under the terms and conditions of the Creative Commons Attribution (CC BY) license (https:/ / creativecommons.org/licenses/by/ $4.0 /)$.

\begin{abstract}
This study examines the impact of capital structure, working capital, and governance quality on the financial performance of small- and medium-sized enterprises in Taiwan using a sample of more than 2000 firms from the Taiwan Economic Journal (TEJ) during the 24-year period of 1995-2018. Panel data are used to create statistics for the regression model. The result shows that a firm's capital structure, represented by the debt ratio, has a significantly negative impact on the firm's financial measures (return on assets (ROA) and return on equity (ROE)), where the working capital, represented by the cash conversion cycle (CCC), has a negative impact and governance quality, represented by the board size, cash dividend distribution, and the percentage of directors, has different impacts.
\end{abstract}

Keywords: capital structure; working capital; governance quality; financial performance

JEL Classification: C58; D24; E22

\section{Introduction}

In a market economy, small and medium enterprises (SMEs) always play an important role and are among the economic sectors that contribute most significantly to economic growth, job creation, and the social welfare of a nation. According to the OECD, SMEs are independent, have a limited number of employees, and vary from country to country. In the European Union, SMEs have fewer than 250 employees, while in the United States they have fewer than 500 employees. According to the Ministry of Economic Affairs, in the manufacturing and construction sector, a small or medium enterprise is defined as a company with less than NTD 80 million (USD 2.6 million) paid-in capital, and, in the service sector, as one with less than NTD 100 million in annual revenue. According to the White Paper on Small and Medium Enterprises (Hsueh et al. 2000), SMEs accounted for $97.64 \%$ of the total number of enterprises in Taiwan at the end of 2018 and $78 \%$ of the total employed population, which was the highest since 2014.

With the increasing role of SMEs in the economy, elucidating how to develop them sustainably has received much attention from business managers and policymakers. Currently, one issue being debated is how the financial performance of SMEs is affected by the capital structure and working capital of enterprises. This comes from the theoretical aspect that the effectiveness of financial management can be positively or negatively affected by the capital structure (Modigliani and Miller 1958; Fama and Miller 1972; Myers and Majluf 1984). In Taiwan, there have been several studies showing problems and countermeasures in the financial management of small and medium-sized enterprises (Wang and Yang 2016). The effectiveness of financial management is reflected in the results of corporate financial activities as an objective measure of the effectiveness of asset use and the company's policies that generate maximum profits (Chakravarthy 1986). 
In Taiwan, the number of SMEs is very large and is more than 1.3 million. To ensure economic growth and create social security jobs, it is necessary to conduct studies to evaluate the current status of operations and the efficiency of SMEs. The purpose of this study is to analyze the main factors that can explain the financial performance of SMEs in the Taiwanese economy. The research objects are the components of capital structure, working capital, governance quality, and financial performance, and their impacts on small and medium-sized enterprises. The range of the study is small and medium enterprises in Taiwan during the period from 1995 to 2018.

This study still has some limitations. The study period is 24 years, so other times have not been fully evaluated. The data are from some small- and medium-sized enterprises and not all. The research method may be incomplete and is unable to fully and comprehensively assess the impact of capital structure and working capital on financial performance. In short, the research limits are the time period (1995-2018) and the scope (2270 SMEs in Taiwan).

The remainder of the paper is organized as follows: In Section 2, we present the literature review. Section 3 describes the research data. Section 4 explains the empirical results. Section 5 provides a conclusion.

\section{Literature Review}

This paper used data from the Taiwan Economic Journal (TEJ) to find the values representing the capital structure of enterprises and their working capital, governance quality, and financial performance to explain relationships. Furthermore, we propose hypotheses about the relationships between capital structure, working capital, governance quality, and financial performance.

Many factors affect a company's financial performance. These include the business situation of the company, development trends, social situation, and policies, etc. To consider the internal factors that will affect financial performance, the factors commonly referred to include (1) capital structure, (2) working capital, (3) and governance quality.

Capital structure: According to Fraser et al. (2007), a firm's capital structure is its permanent long-term financing, represented by long-term debt, preferred stock, common stock, and retained earnings. The funding sources for an enterprise are divided into two categories, namely, liabilities and equity. According to the aforementioned theory of capital structure, a company often considers the following factors when making capital structure decisions: sales stability, asset structure, operating leverage, growth rate, profitability, and taxes (Parrino et al. 2011).

Chinaemerem and Anthony (2012) examined the impact of capital structure on financial performance using a sample of 30 non-financial firms listed on the Nigerian stock exchange. They showed that a firm's capital structure, represented by its debt ratio, has a significant negative impact on its financial measures, and argued that this is evidence in support of agency cost theory. Gleason et al. (2000) also showed a negative relationship between capital structure and performance and suggested that agency issues may lead to the use of higher than appropriate levels of debt in the capital structure, thereby resulting in lower performance. Vătavu (2015) also supported this, where his research found that the most profitable manufacturing companies were those that maintained a high proportion of equity in their capital mix and avoided borrowed funds. The equity of shares has a positive impact on performance indicators, while total debt and short-term debt have negative relationships with ROA and ROE.

The research of Maina and Ishmail (2014) aimed to establish the effect of capital structure on the financial performance of listed companies on the Nairobi Securities Exchange in Kenya. They found that debt and equity were the main determinants of financial performance and showed evidence for a negative and significant relationship between capital structure and all measures of performance.

Notably, Nirajini and Priya's (2013) study of listed trading companies in Sri Lanka showed that there is a positive relationship between capital structure and financial perfor- 
mance. Mujahid and Akhtar's (2014) results also showed a significant positive relationship between capital structure and financial performance and shareholder wealth in the textile sector of Pakistan. Similarly, the work of Adesina et al. (2015) showed that capital structure had a significant positive relationship with the financial performance of quoted banks in Nigeria.

Based on the above scientific evidence, we formulated the first hypothesis of this work:

Hypothesis 1. Capital structure, represented by the debt ratio, has a negative relationship with financial performance.

Working capital: Working capital is understood as "the value of all short-term assets, i.e., assets associated with the business cycle of the company, are transformed into all forms, existing from cash to inventory, accounts receivable, and returned to their original state of cash" (Richards and Laughlin 1980) (Figure 1).

\section{Inventory}

Payable Receivable

\section{Cash}

Figure 1. Working capital turnover.

The cash conversion cycle covers the length of time when money is spent using raw materials to produce finished products, where the products are then sold and money is collected. The financial efficiency of an enterprise may increase or decrease when the cash conversion cycle is shortened or prolonged. The shorter the cash conversion cycle, the higher the net cash flow from business activities and the greater the financial performance of the business. Moreover, shortening the cash conversion cycle means making money quickly to participate in business activities and generating many opportunities to create profit, which will improve results for the company (Enqvist et al. 2014). Raheman et al. (2010), Yegon et al. (2014), and Yazdanfar and Öhman (2014) found that if the results of the cash conversion cycle are significantly negative, this will affect firm performance. Garanina and Belova's (2015) study of 720 Russian companies engaged in various economic activities yielded similar results, and further research revealed that companies should seek to obtain a zero cash conversion cycle in order to increase their rate of return. Nobanee et al. (2011) reviewed a sample of Japanese firms for the period 1990 to 2004 . The results showed a strong negative relationship between the length of the cash conversion cycle and profitability in all of the studied firms, except for consumer goods companies and services companies.

In research based on a report of companies listed on the Istanbul Stock Exchange (ISE) in 2007, Uyar (2009) found a significant negative correlation between CCC and the variables firm size and profitability.

Nobanee (2009) pointed out that shortening the cash conversion cycle will increase a company's profits. They proposed an optimal cash conversion cycle that is more accurate and comprehensive in terms of working capital management. Ebben and Johnson's (2011) research on 879 small manufacturing firms and 833 small retail firms in the US also pointed out that firms with more efficient cash conversion cycles were more liquid, required less 
debt and equity financing, and had higher returns. The study emphasized the importance of the cash conversion cycle as an active management tool for small-business owners.

The shorter the working capital turnover, the higher the liquidity of a business.

Hypothesis 2. Working capital, represented by the cash conversion cycle, has a negative relationship with financial performance.

Governance quality: Corporate governance is a system of rules, mechanisms, and regulations through which businesses are run and controlled. Basically, corporate governance involves balancing the interests of stakeholders, such as shareholders, managers, customers, suppliers, funders, governments, and the community. Corporate governance also establishes principles for achieving company goals, covering all areas of governance from implementation plans and internal control processes to performance measurement, public affairs, and disclosing company information.

There have been many studies on corporate governance and governance quality. Angahar and Mejabi (2014) examined the impact of corporate governance variables to evaluate inactive loans in Nigerian deposit banks. Accounting is also considered an integral part of corporate governance practices. Ekanayake et al. (2009) developed a framework to enable a comprehensive analysis of the role of accounting in corporate governance with special reference to the banking sector. Denis and McConnell (2003) studied international corporate governance, surveying two generations of research on corporate governance systems around the world, focusing on countries other than the United States.

We hypothesize that governance quality, represented by the percentage of independent directors in one enterprise, board size, cash dividend distribution, and firm size, has the following relationships with financial performance:

Hypothesis 3.1. The percentage of independent directors in an enterprise has a negative relationship with financial performance.

Hypothesis 3.2. Board size has a positive relationship with financial performance.

Hypothesis 3.3. Cash dividend distribution has a negative relationship with financial performance.

Hypothesis 3.4. Firm size has a positive relationship with financial performance.

\section{Methodology}

This study aimed to assess the impact of the capital structure, working capital, and governance quality factors on the financial performance of small and medium enterprises in Taiwan. To accomplish this purpose, a regression model was built based on data from more than 2000 Taiwanese enterprises, extracted from the TEJ, that were separated based on the required characteristics (higher and lower P/B ratio and debt ratio-risk level).

This section provides an overview of the variables involved in the regression process, including a table of descriptive statistics and figures of fluctuation for financial performance as expressed through the ROA, ROE, and $\mathrm{P} / \mathrm{B}$ ratio in a year-by-year manner.

Traditional financial performance measures were used to evaluate company performance. Given the characteristics of SMEs in Taiwan, we chose the criteria to assess financial performance based on the research of Ahmad et al. (2012) and Dawar (2014), who used the ROA and ROE in corporate financial statements.

To analyze the impact of capital structure on financial performance, we used the ratio of total debt to total assets (DA) as the independent variable, which was calculated by the following formula:

$$
\mathrm{DA}=\frac{\text { Total Liabilities }}{\text { Total Assets }}
$$


To analyze the impact of working capital on the financial performance of enterprises, the cash conversion cycle (CCC) was used as the independent variable and was calculated by the following formula:

$$
\mathrm{CCC}=\mathrm{ACP}+\mathrm{ICP}-\mathrm{APP}
$$

where CCC is the cash conversion cycle (day), ACP is the average collection period, ICP is the inventory conversion period, and APP is the average paid period.

We can understand that the smaller the CCC, the quicker the business will receive cash, and when the CCC is large, receiving cash will be slow. The components of circulating capital are receivables, inventories, and payables, and maintaining an optimal balance between these components is the primary goal of floating capital governance.

All of the aforementioned criteria are used to assess the management of circulating capital in a certain way, and this paper uses the cash conversion cycle as a measure of floating capital management. The relationship between cash flow and the business cycle is shown as a diagram by Richards and Laughlin (1980) in Figure 2.

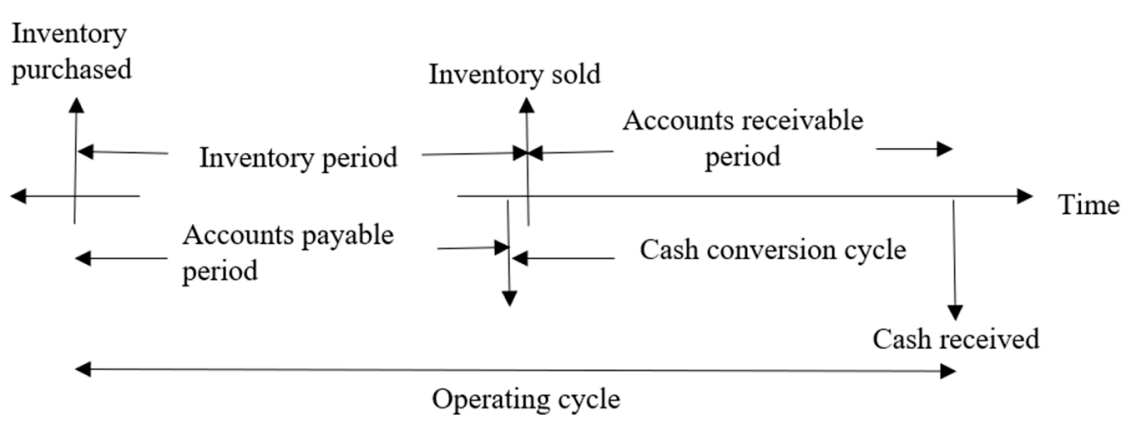

Figure 2. Relationship between cash flow and business cycle as per Richards and Laughlin (1980).

To analyze the impact of governance quality on the financial performance of enterprises, an independent variable board size was used, along with the percentage of independent directors, and cash dividend distribution. The control variable was firm size.

A regression model was built to analyze the impacts of the capital structure, working capital, and governance quality factors on financial performance based on all observations. Then, the price-to-book values were separated into two groups, namely, lower P/B value and higher P/B value. From there, the following regression model was built:

$Y_{i t}=\beta_{0}+\beta_{1}$ Debt $_{i t}+\beta_{2}$ CCC $_{i t}+\beta_{3}$ Board $_{- \text {size }_{i t}}+\beta_{4}$ Cash - dividend $_{i t}+\beta_{5}$ Director $_{i t}+\beta_{6}$ Firm $_{-}$size $_{i t}+u_{i t}$

where $Y_{i t}$ represents the ROA, ROE, and $\mathrm{P} / \mathrm{B}$ of enterprise $i$ at time $t, i=1,2,3,4, \ldots$, and its dependent variables are ROA and ROE; $\beta_{o}$ is the slope of the model; $\beta_{i}$ is the regression coefficient of the variable; $D e b t_{i t}$ is the debt ratio of enterprise $i$ at time $t ; C C C_{i t}$ is the cash conversion cycle of enterprise $i$ at time $t$; Board - size $e_{i t}$ is the board size of enterprise $i$ at time $t$; Cash - dividend $d_{i t}$ is the cash dividend distribution of enterprise $i$ at time $t$; Director it $_{i t}$ is the percentage of independent directors of enterprise $i$ at time $t$; Firm - size $_{i t}$ is the firm size of enterprise $i$ at time $t$; and $u_{i t}$ is the residual of the model.

Company risk was then examined, which is given by a separate debt ratio. The working capital and governance quality factors were examined, which impact the financial performance with two groups, namely, a higher debt ratio and lower debt ratio. From there, the following regression model was built:

$Y_{i t}=\beta_{0}+\beta_{1}$ CCC $_{i t}+\beta_{2}$ Board $_{- \text {size }_{i t}}+\beta_{3}$ Cash - dividend $_{i t}+\beta_{4}$ Director $_{i t}+\beta_{5}$ Firm $_{-}$size $_{i t}+u_{i t}$

where $Y_{i t}$ is the ROA, ROE, and $\mathrm{P} / \mathrm{B}$ of enterprise $i$ at time $t, i=1,2,3,4, \ldots$, and its dependent variables are ROA and ROE; $\beta_{o}$ is the slope of the model; $\beta_{i}$ is the regression coefficient of the variable; $C C C_{i t}$ is the cash conversion cycle of enterprise $i$ at time $t$; Board - size $_{i t}$ is the board size of enterprise $i$ at time $t$; Cash-dividend $d_{i t}$ is the cash dividend 
distribution of enterprise $i$ at time $t$; Director $_{i t}$ is the percentage of independent directors of enterprise $i$ at time $t$; Firm - size $e_{i t}$ is the firm size of enterprise $i$ at time $t$; and $u_{i t}$ is the residual of the model.

Finally, a matrix of the debt ratio affecting the ROA and ROE in enterprises with high/no technology and higher/lower P/B characteristics was built.

\section{Results and Discussion}

The correlation matrix was not built in this paper due to a lack of data with the TEJ. The data related to the analysis process were collected directly based on the actual data in the operation process of small and medium-sized enterprises during 1995-2018. The research data were extracted from the TEJ software, collected from the financial statements (balance sheet and income statement) of more than 2000 small and medium enterprises in Taiwan in 1995-2018, and the sample size included 28,898 observations.

Descriptive statistics include the mean, standard deviation, minimum value (min), and maximum value (max). The statistical results describing the data of observed variables are shown in Table 1.

Table 1. Statistical results describing data of observed variables.

\begin{tabular}{ccccc}
\hline Variable & Mean & Std. Dev & Min & Max \\
\hline ROA (\%) & 1.1771 & 12.1413 & -89.1800 & 86.5100 \\
ROE & 2.6409 & 20.2506 & -116.9600 & 160.5900 \\
P/B & 1.9675 & 2.8462 & 0.0100 & 192.9900 \\
Debt ratio & 0.5277 & 3.1775 & 0.0002 & 221.9410 \\
CCC & 86.2153 & 115.9625 & -601.4000 & 953.3600 \\
Director (\%) & 25.0369 & 16.3234 & 0.0000 & 92.0300 \\
Board size & 2.1659 & 0.3131 & 0 & 3.6109 \\
Cash dividend distribution & 0.0015 & 0.0037 & -0.0542 & 0.1023 \\
Firm size & 14.8772 & 1.9971 & 6.3465 & 25.2373 \\
\hline
\end{tabular}

Regarding return on assets (ROA), from 1995 to 2018, there was a clear difference between the ROA of different enterprises in the SME sector. Specifically, ROA ranged from -89.1800 to 86.5100 and reached an average value of 1.1771. Regarding return on equity (ROE), from 1995 to 2018, there was a clear difference between the ROE of different enterprises in the SME sector. Specifically, ROE ranged from -116.9600 to 160.5900 and reached an average value of 2.6409 .

Price-to-book (P/B) ratio: From 1995 to 2018, there was a clear difference between the $\mathrm{P} / \mathrm{B}$ ratio of different enterprises in the SME sector. Specifically, P/B ranged from 0.0100 to 192.9900 and reached an average value of 1.9675. Regarding the debt to total assets ratio, businesses reached an average of $52.77 \%$.

Cash conversion cycle (CCC): The average cash conversion cycle of companies in the sample was 86 days (about 3 months). Regarding the percentage of independent directors in one enterprise, businesses had an average of $25.0369 \%$. Regarding board size, the average natural logarithm of the number of board members was 2.1659. Regarding cash dividend distribution, small and medium-sized businesses in Taiwan ranged from -0.0542 to 0.1023 and reached an average of 0.0015 . Regarding firm size, the natural logarithm of total assets of small and medium-sized businesses in Taiwan ranged from 6.3465 to 25.2373 and reached an average of 14.8772 .

The ROA and ROE data have been fully updated by TEJ since 2012. As shown in Figures 3 and 4, from 2013 to 2018, the ROA ratio ranged from $-1.0152 \%$ to $2.0880 \%$ and the ROE ratio ranged from $-1.8776 \%$ to $4.4395 \%$ (after a marked slowdown in 2011, where global economic growth remained tepid in 2012, with most regions expanding at a pace below the potential). Especially in 2018, the ROE of small and medium enterprises greatly exceeded the ROA $(4.4395 \%$ and $2.0880 \%)$. Compared to the average GDP growth rate of Taiwan over the years of about $2.3667 \%$, this shows good and synchronous development of the financial efficiency of small and medium enterprises. 


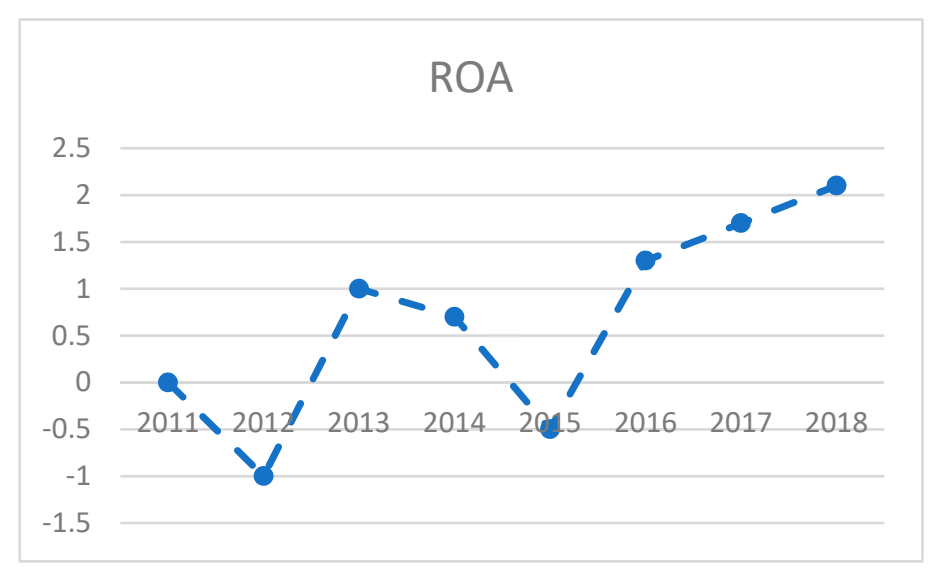

Figure 3. Fluctuations of average ROA over the years.

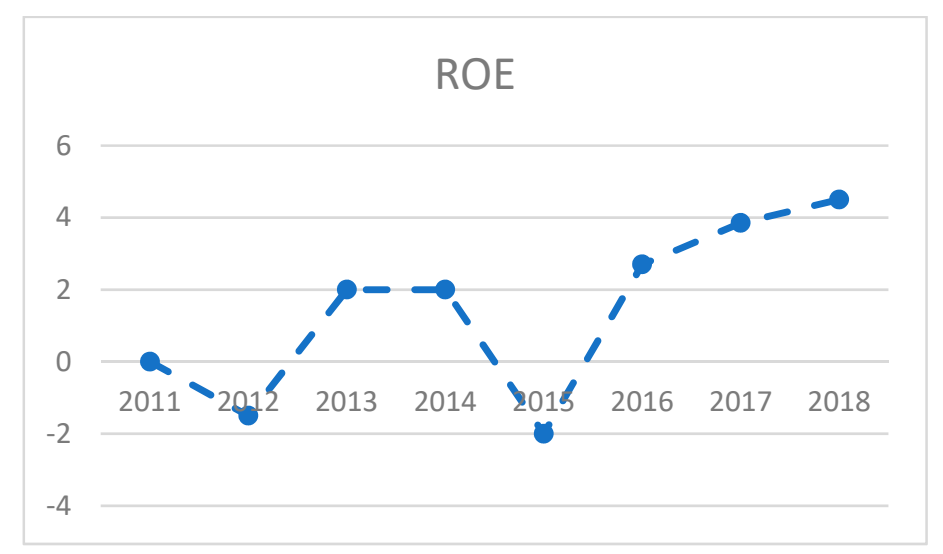

Figure 4. Fluctuations of average ROE over the years.

This situation shows that, in general, because the technology of SMEs is gradually being improved, the management level is also improved, so the financial efficiency is equivalent to the growth rate of the country; however, small- and medium-sized enterprises with low profitability may still be more limited in terms of endogenous capital and financial instability when their management is not good and the full potential of production and business activities is not promoted.

As shown in Figure 5, the price to book ratio fluctuated from 1 to 3 from 1995 to 2018. The years when the $\mathrm{P} / \mathrm{B}$ ratio showed signs of decline or bottoming out were 2000, 2008, 2011, and 2015, and these were points when the world economy slowed down the pace of development, and medium and small businesses in Taiwan are inevitably affected by the global economy. After that, the P/B ratio increased again due to the stable economy and safe development environment, which is a good sign.

As shown in Figure 6, from 1995 to 1998, the average debt ratio of SMEs was relatively high (greater than $100 \%$ ) but still yielded good business results, as expressed by the P/B ratio, which also performed well (average $\mathrm{P} / \mathrm{B}$ ratio greater than 2 ). Over time, with the development of the economy, the average debt ratio over the years of stability always fluctuated around 40-50\%. The highest P/B value between 1999 and 2018 was 2.3796 in 2009, which is the year the economy was recovering from the global economic crisis. At that time, the average debt ratio of SMEs in Taiwan was $44.54 \%$. 


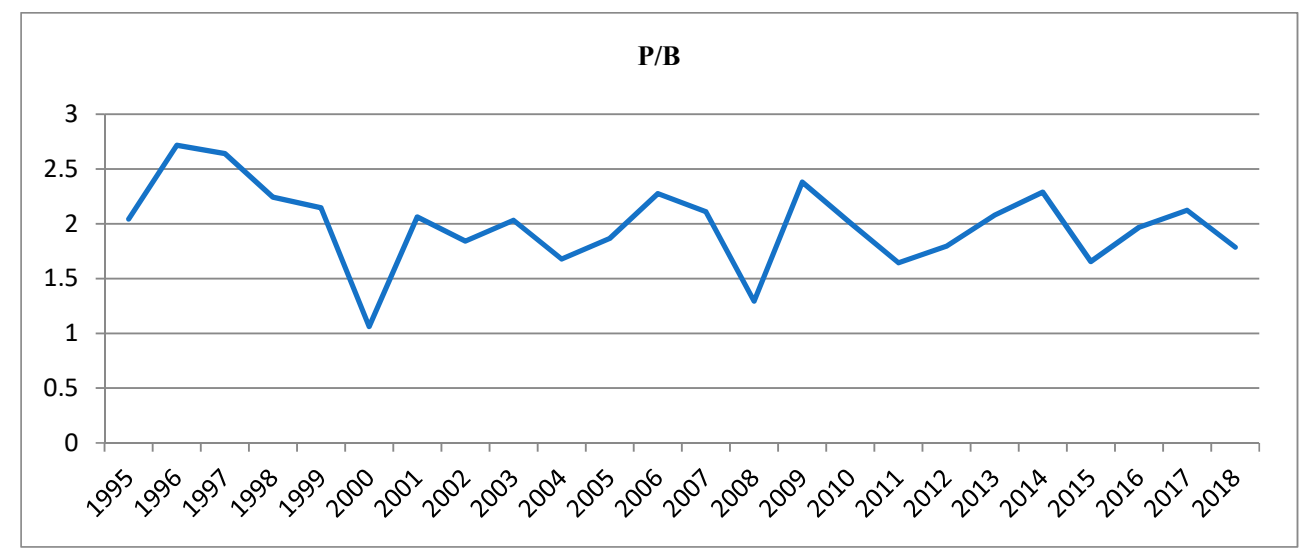

Figure 5. Fluctuations of average P/B over the years.

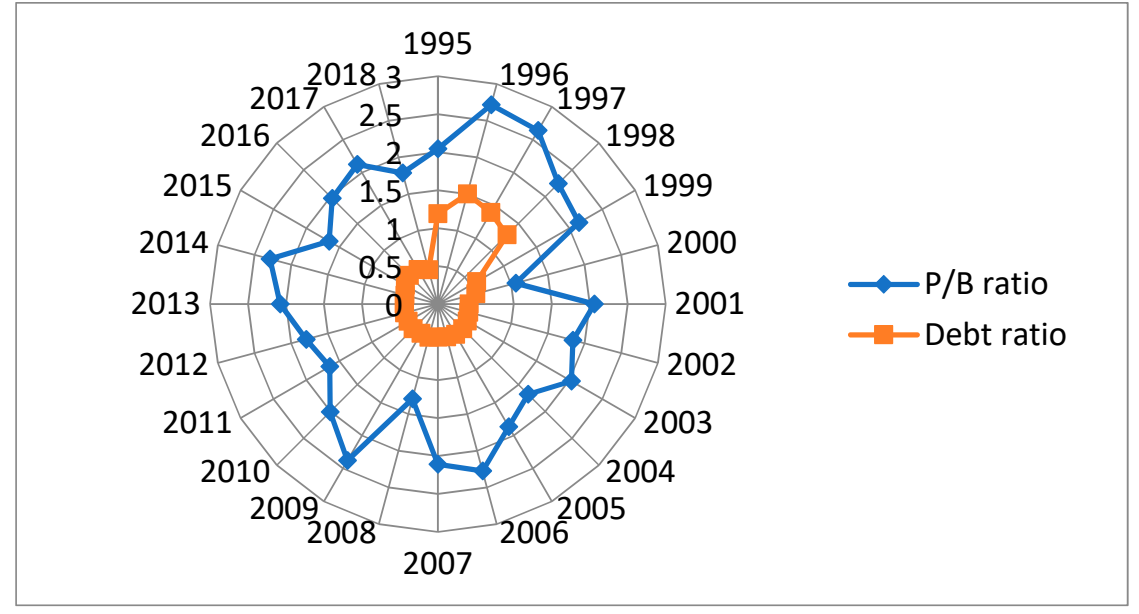

Figure 6. Volatility of average $\mathrm{P} / \mathrm{B}$ ratio and average debt ratio over the years.

Regression results: This section shows the regression results after separating according to $\mathrm{P} / \mathrm{B}$ ratio or debt ratio. We built a matrix of the impact of debt ratio on $\mathrm{ROA}$ and $\mathrm{ROE}$ with two related conditions, technology and $\mathrm{P} / \mathrm{B}$, ratio to see the difference between high-tech and non-tech industry characteristics.

According to the regression results in Table 2, in the period of 1995-2018, we can see that the variable total debt to total assets (debt ratio) negatively impacted the financial performance of SMEs. Specifically, the regression coefficient $\beta_{\text {Debt ratio }}$ reached -3.4275 with regard to ROA variables and -23.5815 with regard to ROE variables, i.e., with other factors constant, if the debt ratio increases (decreases) by 1 unit, the ROA of the SME sector decreases (increases) by 3.4275 units; with other factors unchanged, if the debt ratio increases (decreases) by 1 unit, the ROE decreases (increases) by 23.5815 units. This means that companies with a low debt ratio or low risk tolerance have better financial performance than businesses with a high debt ratio or higher risk tolerance. The difference in the debt ratio comes from the company equity capacity, or the intention to use a high debt ratio as financial leverage to promote the company's financial performance. Hypothesis 1 is correct.

According to the regression results, in the period of 1995-2018, we can see that the variable cash conversion cycle negatively impacted the financial performance of SMEs. With other factors constant, if the CCC increases (decreases) by 1 unit, the ROA of the SME sector decreases (increases) by 0.0091 units; with other factors unchanged, if the CCC increases (decreases) by 1 unit, the ROE decreases (increases) by 0.0072 units. CCC's impact on ROA is stronger than its impact on ROE. Hypothesis 2 is correct. 
Table 2. Regression results of all observations.

\begin{tabular}{ccc}
\hline & ROA & ROE \\
\hline Debt ratio & $-3.4275^{* *}$ & $-23.5815^{* *}$ \\
CCC & $-0.0091^{*}$ & $-0.0072^{*}$ \\
Board size & $-8.4426^{* *}$ & $-3.5478^{* *}$ \\
Cash dividend distribution & $506.6534^{* *}$ & $1612.2900^{* *}$ \\
Director $(\%)$ & $-0.1122^{* *}$ & $0.1181^{* *}$ \\
Firm size & $1.1731^{* *}$ & $4.8615^{* *}$ \\
\hline
\end{tabular}

* and ${ }^{* *}$ denote significance at the $10 \%$ and $1 \%$ levels, respectively.

With governance quality, the variable board size shows a negative relationship with financial performance. The effect of board size on ROA is stronger than its effect on ROE. The effect of board size on ROA is 2.5 times the effect on ROE. Hypothesis 3.1 is correct.

In contrast to board size, cash dividend distribution shows a positive relationship with financial performance. The effect of cash dividend distribution on ROE is stronger than its effect on ROA (by around 3 times). Hypothesis 3.2 is correct.

The variable percentage of independent directors shows different effects on ROA and ROE. It shows a negative relationship with ROA, that is, with other factors constant, if the percentage of independent directors increases (decreases) by 1 unit, the ROA of the SME sector decreases (increases) by 0.1122 units. The variable shows a positive relationship with ROE; that is, with other factors constant, if it decreases (increases) by 1 unit, the ROE decreases (increases) by 0.1181 units. Hypothesis 3.3 is undefined.

The regressive value of firm size shows a positive relationship with financial performance. Specifically, the impact of firm size on ROE is stronger than its impact of on ROA (by about 4 times). With other factors constant, if firm size increases (decreases) by 1 unit, the ROA of the SME sector increases (decreases) by 1.1731 units; with other factors unchanged, if firm size increases (decreases) by 1 unit, the ROE increases (decreases) by 4.8615 units. Hypothesis 3.4 is correct.

Regression results after separate $\mathrm{P} / \mathrm{B}$ ratio: According to the regression results, in the period of 1995-2018, we can see that the variable total debt to total assets (debt ratio) negatively impacted the financial performance of SMEs. Specifically, the regression coefficient $\beta_{\text {Debt ratio }}$ reached -1.3775 for companies with higher $\mathrm{P} / \mathrm{B}$ and -10.5168 for those with lower $\mathrm{P} / \mathrm{B}$ with regard to ROA variables and -18.0553 for those with higher $\mathrm{P} / \mathrm{B}$ and -22.9005 for those with lower $\mathrm{P} / \mathrm{B}$ with regard to ROE variables, i.e., with other factors constant, if the DA ratio increases (decreases) by 1 unit, the ROA of the SME sector decreases (increases) in the range of 1.3775 to 10.5168 units; with other factors unchanged, if the debt ratio increases (decreases) by 1 unit, the ROE decreases (increases) in the range of 18.0553 to 22.9005 units. This means that companies with a low debt ratio or low risk tolerance have better financial performance than businesses with a high debt ratio or higher risk tolerance. The difference in the debt ratio comes from the company equity capacity, or the intention to use a high debt ratio as financial leverage, promoting the company's financial performance. This result agrees with the studies of Chinaemerem and Anthony (2012), Gleason et al. (2000), Vătavu (2015), and Maina and Ishmail (2014), among others.

According to the regression results in Table 3, in the period of 1995-2018, we can see that the variable cash conversion cycle negatively impacted the financial performance of SMEs. With other factors constant, if the CCC increases (decreases) by 1 unit, the ROA of the SME sector decreases (increases) in the range of 0.0059 to 0.0189 units; with other factors unchanged, if the CCC increases (decreases) by 1 unit, the ROE level decreases (increases) in the range of 0.0056 to 0.0140 units. This is entirely consistent with reality. The goal is to shorten the cash conversion cycle as much as possible without affecting the company's financial management efficiency. This will increase profits, because the longer the cash conversion cycle, the greater the need for external financing, and the more the funding will increase the cost of capital and thus reduce the economic value of the company. 
Table 3. Regression results with a separate $\mathrm{P} / \mathrm{B}$ ratio.

\begin{tabular}{|c|c|c|c|c|c|c|}
\hline & \multicolumn{3}{|c|}{ ROA } & \multicolumn{3}{|c|}{ ROE } \\
\hline & High P/B & Low $\mathrm{P} / \mathrm{B}$ & Difference & High P/B & Low $\mathrm{P} / \mathrm{B}$ & Difference \\
\hline Debt ratio & $-1.3775^{* * *}$ & $-10.5168^{* * *}$ & 9.1393 & $-18.0553^{* * *}$ & $-22.9005^{* * *}$ & 4.8452 \\
\hline CCC & $-0.0189 *$ & $-0.0059 *$ & 0.0130 & $-0.0140 *$ & $-0.0056^{*}$ & 0.0084 \\
\hline Board size & $-3.8267^{* *}$ & $-0.5025^{* *}$ & 3.3242 & $-9.2522 * * *$ & $-0.8572 * *$ & 8.3950 \\
\hline Cash dividend distribution & $910.6103 * * *$ & $899.8833^{* * *}$ & 10.7270 & $1530.1180^{* * *}$ & $2042.1280 * * *$ & 512.0100 \\
\hline Director \% & $0.1030 * * *$ & $0.0411^{* * *}$ & 0.0619 & $0.1832 * * *$ & $0.0597^{* * *}$ & 0.1235 \\
\hline Firm size & $5.6304^{* * *}$ & $1.5528 * * *$ & 4.0776 & $9.6493 * * *$ & $3.4445^{* * *}$ & 6.2048 \\
\hline
\end{tabular}

$* * * *$, and ${ }^{* * *}$ denote significance at the $10 \%, 5 \%$, and $1 \%$ levels, respectively.

With governance quality, while board size shows a negative relationship with financial performance, cash dividend distribution and percent of independent directors show the opposite relationship. Board size has a stronger effect on companies with a high $\mathrm{P} / \mathrm{B}$ than those with a low $\mathrm{P} / \mathrm{B}$ ratio. A change in board size does not significantly affect the ROA or $\mathrm{ROE}$ of companies with a low $\mathrm{P} / \mathrm{B}$ ratio when the regression index is always less than 1 (specifically 0.5025 and 0.8572 ). Cash dividends are distributions of money or payments to shareholders that are generally a part of current income or accrued profits. The greater the value of the cash dividend distribution, the more efficient the business is, and vice versa. The percent of independent directors shows a positive relationship to the ROE of SMEs in Taiwan and the ROA of businesses with a low $\mathrm{P} / \mathrm{B}$ ratio, but the impact is insignificant.

The regressive value of firm size shows a positive relationship with financial performance. Specifically, firm size has a stronger impact on firms with a higher $\mathrm{P} / \mathrm{B}$ ratio than those with a lower $\mathrm{P} / \mathrm{B}$ ratio (both ROA and $\mathrm{ROE}$ are about three times higher). With other factors constant, if firm size increases (decreases) by 1 unit, the ROA of the SME sector increases (decreases) in the range of 1.5528 to 5.6304 units; with other factors unchanged, if firm size increases (decreases) by 1 unit, the ROE increases (decreases) in the range of 3.4445 to 9.6493 units.

Regression results after separate debt-ratio: The debt ratio measures the level of leverage used by a firm in terms of total debt to total assets. Used in conjunction with other financial health measures, debt ratios can help investors determine a company's level of risk.

According to the regression results in Table 4, after the debt ratios of businesses were separated, CCC still showed a negative relationship with financial performance. The difference in the impact of CCC on financial performance was insignificant between businesses with lower and higher debt ratios; in general, the negative impact for businesses with a high debt ratio is higher (ROA: -0.0050 (high debt ratio), -0.0110 (low debt ratio); ROE: -0.0074 (high debt ratio), -0.0091 (low debt ratio)).

Table 4. Regression results after separate debt ratio.

\begin{tabular}{ccccccc}
\hline & \multicolumn{3}{c}{ ROA } & & ROE \\
\hline & Higher Debt & Lower Debt & Difference & Higher Debt & Lower Debt & Difference \\
\hline CCC & $-0.0050^{*}$ & $-0.0074^{*}$ & 0.0024 & $-0.0110^{*}$ & $-0.0091^{*}$ & 0.0019 \\
Board size & $-0.3629^{* *}$ & $-2.9340^{* *}$ & 2.5711 & $-1.8177^{* *}$ & $-4.7065^{* *}$ & 2.8888 \\
Cash dividend distribution & $476.1162^{* * *}$ & $2180.8550^{* * *}$ & 1704.7388 & $1146.1940^{* * *}$ & $3124.2270^{* * *}$ & 1978.0330 \\
Director \% & $0.0703^{* * *}$ & $0.0749^{* * *}$ & 0.0046 & $0.1333^{* * *}$ & $0.1081^{* * *}$ & 0.0252 \\
Firm size & $1.6425^{* * *}$ & $3.8583^{* * *}$ & 2.2158 & $3.7554^{* * *}$ & $5.1029^{* * *}$ & 1.3475 \\
\hline
\end{tabular}

$* * *$, and ${ }^{* * *}$ denote significance at the $10 \%, 5 \%$, and $1 \%$ levels, respectively.

With governance quality, board size still shows a negative relationship with financial performance. The effect of board size is stronger for companies with a low debt than those with a high debt ratio. The effect of board size on the ROA of enterprises with a lower debt ratio is 8 times lower than that of enterprises with a low debt ratio. Similarly, the effect of 
board size on the ROE of enterprises with a low debt ratio is 3 times higher than that of enterprises with a high debt ratio.

For businesses with a higher debt ratio, equivalent to a higher level of risk, the influence of cash dividend distribution is less than for businesses with a lower debt ratio, equivalent to a lower level of risk. Specifically, with other factors constant, if the cash dividend distribution increases (decreases) by 1 unit, the ROA of SMEs with a higher debt ratio will increase (decrease) by 476.1162 units, and that of SMEs with a lower debt ratio will increase (decrease) by 2180.8550 units. With other factors constant, if the cash dividend distribution increases (decreases) by 1 unit, the ROE of SMEs with a higher debt ratio will increase (decrease) by 1146.1940 units and that of SMEs with a lower debt ratio will increase (decrease) by 3124.2270 units.

The percent of independent directors shows a positive relationship with the ROA and ROE of SMEs in Taiwan. This variable has a stronger impact on ROA for firms with a lower debt ratio than firms with a higher debt ratio (0.0749 and 0.0703 , respectively). It has a stronger impact on ROE for firms with a higher debt ratio than firms with a lower debt ratio ( 0.1333 and 0.1081 , respectively).

The regressive value of firm size shows a positive relationship with financial performance. Specifically, firm size has a stronger impact on firms with a low debt ratio than firms with a high debt ratio (ROA is about 2.5 times and ROE about 1.5 times higher). With other factors constant, if firm size increases (decreases) by 1 unit, the ROA of the SME sector increases (decreases) in the range of 1.6425 to 3.8583 units; with other factors unchanged, if firm size increases (decreases) by 1 unit, the ROE increases (decreases) in the range of 3.7554 to 5.1029 units.

Regression results with matrix high tech and non-high tech: In general, the debt ratio still shows a negative relationship with the financial performance of SMEs in Taiwan even when it comes to separate technology. Panel A shows the impact of the debt ratio on ROA. From this panel, it can be seen clearly that the impact of the debt ratio on the ROA of high-technology businesses (-27.2098) is stronger than that of non-high-technology businesses with a higher $\mathrm{P} / \mathrm{B}$ ratio $(-3.9906)$ and with a lower $\mathrm{P} / \mathrm{B}$ ratio $(-15.2829)$. The impact of the debt ratio on the ROA of non-high-technology businesses with a lower $\mathrm{P} / \mathrm{B}$ ratio (-9.3934) is stronger than that of such businesses with a higher $\mathrm{P} / \mathrm{B}$ ratio.

According to the regression results in Table 5, from the regression results in panel $B$, it can be seen that the negative effect of the debt ratio on the ROE of non-high-tech enterprises has a higher price-to-book ratio (-69.6129), which is larger than the effect of the debt ratio on the ROA of high-tech and non-high-tech businesses. In high-tech businesses with a higher $\mathrm{P} / \mathrm{B}$ ratio, this impact is not very different when the value is also very large (-68.7596). The negative impact of the debt ratio on the ROE of high-tech and non-high-tech businesses with a lower $\mathrm{P} / \mathrm{B}$ ratio is -29.2456 and -23.8156 , respectively. With other factors unchanged, if the debt ratio increases (decreases) by 1 unit, the ROE of high-tech companies with a lower $\mathrm{P} / \mathrm{B}$ ratio decreases (increases) by 29.2456 units; the ROE of non-high-tech companies with a lower P/B ratio decreases (increases) by 23.8156 units.

Table 5. Impact of debt ratio on ROA and ROE of high-tech and non-high-tech businesses.

\begin{tabular}{ccc}
\hline Panel A: Debt Ratio Affects ROA & High-Tech & Non-High-Tech \\
\hline Higher P/B & $-27.2098^{* * *}$ & $-3.9906^{* * *}$ \\
Lower P/B & $-15.2829^{* * *}$ & $-9.3934^{* * *}$ \\
\hline Panel B: Debt Ratio Affects ROE & High-Tech & Non-High-Tech \\
\hline Higher P/B & $-68.7596^{* * *}$ & $-69.6129^{* * *}$ \\
Lower P/B & $-29.2456^{* *}$ & $-23.8156^{* * *}$ \\
\hline
\end{tabular}

*** denote significance at the $1 \%$ level, respectively. 


\section{Conclusions}

The goal of an enterprise's financial governance is to make financial decisions, such as investment, funding, and distribution decisions, which are considered the most important decisions of the company because they create corporate value. The decision to invest in movable assets using leverage is indispensable when assessing a company's financial situation through the figures in financial statements. A proper capital structure and working capital will lead to success and maximize benefits for business owners, whereas wrong decisions regarding capital structure and working capital will make businesses pay a high price and even go bankrupt or have to sell their assets to in order restructure operations. As such, determining the impact of capital structure, floating capital, and governance quality on the efficiency of financial management is very important for businesses in order to have the right direction in a competitive market.

Based on that, this study describes the situation of the capital structure, working capital, governance quality, and financial performance of more than 2000 small and medium enterprises in Taiwan from 1995 to 2018. For capital structure, reducing the debt ratio will increase financial performance. For circulating capital, shortening the cash conversion cycle will increase financial management efficiency. For governance quality, the board size shows a negative relationship to financial performance, that is, limiting the board size will have a positive effect on financial performance. The cash dividend distribution shows a positive relationship with financial performance. An increase in cash dividends proves the outstanding performance of the enterprise. Using the regression model before separation, the percentage of independent directors had a negative relationship with ROA, but after separating the $\mathrm{P} / \mathrm{B}$ and debt ratios, the result shows a positive relationship with both ROA and ROE.

The limitation of the study is that only about 2000 SMEs in Taiwan have reported their data on TEJ. The timeframe of the report ended in 2018 and the report has only analyzed the impacts of endogenous factors in SMEs that affect financial performance. This report opens a new research direction, which is the influence of external factors on the financial performance of SMEs in Taiwan in the period 2019-2021, specifically the impact of the COVID-19 pandemic. In particular, how has COVID-19 affected the financial performance of SMEs in Taiwan when compared with previous results?

Author Contributions: Data curation, A.-H.V.T.; formal analysis, T.-D.P.; methodology, A.-H.V.T.; writing - review and editing, T.-D.P. Both authors have read and agreed to the published version of the manuscript.

Funding: This research received no external funding.

Institutional Review Board Statement: Authors followed the APA Ethical Principles of Psychologists and Code of Conduct 2010 and 2016 Amendments.

Informed Consent Statement: Not applicable.

Data Availability Statement: Publicly available datasets were analyzed in this study. This data can be found here: https:/ / www.finasia.biz/ (accessed date: 2 May 2021).

Conflicts of Interest: The authors declare no conflict of interest.

\section{References}

Adesina, Julius B., Barine M. Nwidobie, and Oluwatosin O. Adesina. 2015. Capital structure and financial performance in Nigeria. International Journal of Business and Social Research 5: 21-31.

Ahmad, Zuraidah, Norhasniza Mohd Hasan Abdullah, and Roslan Shashazrina. 2012. Capital Structure Effect on Firms Performance: Focusing on Consumers and Industrials Sectors on Malaysian Firms. International Review of Business Research Papers 8: 137-55.

Angahar, Paul Aondona, and Simon Kolawole Mejabi. 2014. The impact of corporate governance variables on non-performing loans of Nigerian deposit money banks. Asian Economic and Financial Review 4: 1531.

Chakravarthy, Balaji S. 1986. Measuring strategic performance. Strategic Management Journal 7: 437-58. [CrossRef]

Chinaemerem, Osuji Casmir, and Odita Anthony. 2012. Impact of capital structure on the financial performance of Nigerian firms. Arabian Journal of Business and Management Review (OMAN Chapter) 1: 43. [CrossRef] 
Dawar, Varun. 2014. Agency theory, capital structure and firm performance: Some Indian evidence. Managerial Finance 40: 1190-206. [CrossRef]

Denis, Diane K., and John J. McConnell. 2003. International corporate governance. Journal of Financial and Quantitative Analysis 38: 1-36. [CrossRef]

Ebben, Jay J., and Alec C. Johnson. 2011. Cash conversion cycle management in small firms: Relationships with liquidity, invested capital, and firm performance. Journal of Small Business E Entrepreneurship 24: 381-96.

Ekanayake, Athula, Hector Perera, and Sujatha Perera. 2009. Towards a framework to analyse the role of accounting in corporate governance in the banking sector. Journal of Applied Management Accounting Research 7: 21.

Enqvist, Julius, Michael Graham, and Nikkinen Jussi. 2014. The Impact of Working Capital Management on Firm Profitability in Different Business Cycles: Evidence from Finland. Research in International Business and Finance 32: 36-49. [CrossRef]

Fama, Eugene F., and Merton H. Miller. 1972. The Theory of Finance. In FAMA the Theory of Finance. New York: Holt, Rinehart, and Winston.

Fraser, Lyn M., Aileen Ormiston, and Lyn M. Fraser. 2007. Understanding Financial Statements, 8nd ed. Hoboken: Prentice Hall.

Garanina, Tatiana A., and Olga A. Belova. 2015. Liquidity, cash conversion cycle and financial performance: Case of Russian companies. Investment Management and Financial Innovations 12: 90-100.

Gleason, Kimberly C., Lynette Knowles Mathur, and Ike Mathur. 2000. The interrelationship between culture, capital structure, and performance: Evidence from European retailers. Journal of Business Research 50: 185-91. [CrossRef]

Hsueh, L., A. Lin, S. Wang, and G. Okrasa. 2000. White Paper on Small and Medium Enterprises in Taiwan; Taiwan: Small and Medium Enterprise Administration, Ministry of Economic Affairs.

Maina, Leonard, and Mwasa Ishmail. 2014. Capital structure and financial performance in Kenya: Evidence from firms listed at the Nairobi Securities Exchange. International Journal of Social Sciences and Entrepreneurship 1: 209-23.

Modigliani, Franco, and Merton H. Miller. 1958. The cost of capital, corporation finance and the theory of investment. The American Economic Review 48: 261-97.

Mujahid, Mubeen, and Kalsoom Akhtar. 2014. Impact of capital structure on firms financial performance and shareholders wealth: Textile Sector of Pakistan. International Journal of Learning and Development 4: 27-33. [CrossRef]

Myers, Stewart C., and Nicholas S. Majluf. 1984. Corporate financing and investment decisions when firms have informationthat investors do not have, National Bureau of Economic Research. Journal of Financial Economics 13: 187-221. [CrossRef]

Nirajini, A., and Kogulan Priya. 2013. Impact of capital structure on financial performance of the listed trading companies in Sri Lanka. International Journal of Scientific and Research Publications 3: 1-9.

Nobanee, Haitham, Modar Abdullatif, and Maryam AlHajjar. 2011. Cash conversion cycle and firm's performance of Japanese firms. Asian Review of Accounting 19: 147-56. [CrossRef]

Nobanee, Haitham. 2009. Working Capital Management and Firm's Profitability: An Optimal Cash Conversion Cycle (September 10). Available online: https:/ / ssrn.com/abstract=1471230 (accessed on 7 June 2021).

Parrino, Robert, David Kidwell, and Bates Thomas. 2011. Fundamentals of Corporate Finance, 2nd ed. Hoboken: Wiley Publisher.

Raheman, Abdul, Talat Afza, Abdul Qayyum, and Mahmood Ahmed Bodla. 2010. Working capital management and corporate performance of manufacturing sector in Pakistan. International Research Journal of Finance and Economics 47: 156-69.

Richards, Verlyn D., and Eugene J. Laughlin. 1980. A cash conversion cycle approach to liquidity analysis. Financial Management 9: 32-38. [CrossRef]

Uyar, Ali. 2009. The relationship of cash conversion cycle with firm size and profitability: An empirical investigation in Turkey. International Research Journal of Finance and Economics 24: 186-93.

Vătavu, Sorana. 2015. The impact of capital structure on financial performance in Romanian listed companies. Procedia Economics and Finance 32: 1314-22. [CrossRef]

Wang, Mei-Hsiang, and Tarng-Yao Yang. 2016. Investigating the success of knowledge management: An empirical study of small-and medium-sized enterprises. Asia Pacific Management Review 21: 79-91. [CrossRef]

Yazdanfar, Darush, and Peter Öhman. 2014. The impact of cash conversion cycle on firm profitability. International Journal of Managerial Finance 10: 442-52. [CrossRef]

Yegon, Charles Kiprotich, Kirui Joseph Kiprono, and Chepkutto Willy. 2014. Working capital management and corporate financial performance: Evidence from panel data analysis of selected quoted tea companies in Kenya. Research Journal of Finance and Accounting 5: 53-62. 